\title{
Erythropoiesis in the Anemia of Bone Marrow Failure
}

\author{
Raymond Alexantan and Clafence Alfrey \\ From the Departments of Medicine, The University of Texas M. D. Anderson \\ Hospital and Tumor Institute and Baylor College of Medicine, \\ Houston, Texas 77025
}

\begin{abstract}
A BSTRACT The quantitative relationship between red cell volume, erythropoietin level, and erythropoiesis was evaluated in 43 human beings. Results in normal man were compared with studies in patients with anemia from bone marrow failure and with polycythemia vera. The maximum erythropoietin excretion after bleeding normal men was similar to the basal levels found in patients with chronic anemia of similar magnitude. Although erythropoietin values were low in patients with polycythemia vera, bleeding evoked a normal response. In patients anemic from bone marrow failure, basal levels were elevated, and phlebotomy resulted in an increase consistent with the new level of anemia. These observations indicate that erythropoietin level is affected primarily by the degree of anemia and is not influenced by the duration of anemia. In normal subjects, a fivefold increase in urinary erythropoietin was associated with a doubling of erythropoiesis. Despite similar degrees of erythropoietin production, anemic patients with evidence of bone marrow in the lower extremities had greater red cell production. In patients with polycythemia vera, red cell production was inappropriately elevated with regard to the urinary erythropoietin excretion. Bone marrow maturation time was not shortened in patients anemic from bone marrow failure to the same degree as in bled, normal volunteers. In addition to an adequate level of erythropoietin production, normal bone marrow function is necessary for maximal shortening of maturation time.
\end{abstract}

\section{INTRODUCTION}

Erythropoietin production is regulated primarily by tissue requirements for oxygen (1), and increased quantities provide a major adaptation to anemia (2). In normal man, the kinetics of the erythropoietin response to bleeding has not been clearly documented; nor has the influence of polycythemia vera or anemia on the mag-

Received for publication 13 April 1970 and in revised form 29 June 1970. nitude of erythropoietin production after phlebotomy been evaluated. This report correlates the urinary erythropoietin excretion with the degree of anemia and with the level of erythropoiesis in normal subjects, patients with polycythemia vera, and patients with chronic anemia from bone marrow failure. Predictable erythropoietin elevation in response to increasing anemia occurred in all patient groups. In normal subjects, a close relationship was apparent between the level of erythropoietin excretion and the degree of erythropoiesis. In patients with bone marrow failure, the presence of bone marrow in the extremities was associated with an increased rate of erythropoiesis for a specific magnitude of erythropoietin production. By the combined use of erythropoietin and erythrokinetic techniques, the functional capacity of the bone marrow was better defined.

\section{METHODS}

Included in this report are studies of erythropoietin and erythrokinetics in 9 normal volunteers, 22 patients with chronic anemia from bone marrow failure, and 12 patients with polycythemia vera.

\section{Measurements of erythropoiesis}

Erythropoiesis was evaluated from the plasma iron turnover, the erythron iron turnover, the uptake of ${ }^{\circ 0} \mathrm{Fe}$ in the lower extremities after $24 \mathrm{hr}$, and the red cell utilization of ${ }^{50} \mathrm{Fe}$ from days 1 to 7 . Plasma iron turnover studies were initiated between 9 and 11 a.m. by the injection of 6-12 $\mu \mathrm{Ci}$ of citrated ${ }^{50} \mathrm{Fe}$ previously incubated with $6-9 \mathrm{ml}$ of normal plasma. The dose of injected ${ }^{80} \mathrm{Fe}$ was determined by a gravimetric technique (3). Blood was collected at measured time intervals for $120 \mathrm{~min}$, and the $t_{1}$ of plasma clearance was calculated. Plasma iron turnover was calculated by the formula of Bothwell and Finch (4) from the mean serum iron measurements before and $2 \mathrm{hr}$ after ${ }^{\circ 0} \mathrm{Fe}$ injection. Erythron iron turnover was derived by subtracting the calculated nonerythron turnover from the plasma iron turnover (5). Plasma and erythron iron turnovers in milligrams per day were calculated from the product of the plasma or erythron iron turnover per $100 \mathrm{ml}$ of whole blood $(4,5)$ and the blood volume derived from the red cell volume. In normal subjects, the blood volume was calculated from the red cell volume using a body hematocrit 
to venous hematocrit ratio of 0.92 ; in nine polycythemic patients with moderate splenomegaly, a ratio of 0.98 was assumed; in three patients with marked splenomegaly, a ratio of 1.04 was used (6). Red cell volume was measured on the 7th day after ${ }^{\circ 0} \mathrm{Fe}$ injection using a ${ }^{\circ 1} \mathrm{Cr}$ gravimetric technique (7), and the results also were used to quantitate the per cent uptake of ${ }^{50} \mathrm{Fe}$ in the red cell mass. Fixed red cell iron turnover (milligrams per day) was determined from the product of the plasma iron turnover and the per cent utilization of the injected dose of ${ }^{50} \mathrm{Fe}$ in the red cell volume after 7 days. A linear body scanner was used to evaluate extension of the marrow erythron into the extremities (8). Significant extension was identified when ${ }^{50} \mathrm{Fe}$ uptake below the midthigh exceeded $10 \%$ (normal range $2-7 \%$ ) in association with an unequivocal peak of radioactivity over the knees, present at $24 \mathrm{hr}$ but absent 7 days after ${ }^{50} \mathrm{Fe}$ injection. Marrow iron transit time was assessed from the interval between ${ }^{50} \mathrm{Fe}$ injection to the appearance of $50 \%$ of the maximum ${ }^{50} \mathrm{Fe}$ level in the red cell volume (9). Bone marrow erythroid cellularity was calculated to the nearest $5 \%$ from the product of the per cent of erythroblasts (determined from the differential count of 1000 cells on Wright's-stained smears) and the per cent of bone marrow space occupied by cells on fixed clot sections (10). Iron deficiency was recognized when marrow hemosiderin was absent, the serum iron was less than $60 \mu \mathrm{g} / 100 \mathrm{ml}$ and the per cent saturation of transferrin was less than $18 \%$.

\section{Erythropoietin assay}

Erythropoietin production was assessed from the urinary erythropoietin excretion. Dialyzed concentrates were pre- pared from 24-hr urine collections and assayed in polycythemic mice as previously described (11). Polycythemia was induced by exposing animals to 0.27 atm daily for $8 \mathrm{hr}$ for at least $4 \mathrm{wk}$. This degree of hypoxia was tolerated by' reducing the chamber temperature to less than $22^{\circ} \mathrm{C}$ with an air conditioning apparatus, reducing humidity by withdrawing water bottles, and exposing mice to 0.37 and $0.32 \mathrm{~atm}$ for the first two 8-hr exposures. The mean of two to four different urinary erythropoietin determinations on separate urine collections was used to confirm results which were expressed in Standard B units per day. Multiple measurements were used to confirm a value because of the low reproducibility of the bioassay method for erythropoietin. For example, the urinary erythropoietin excretion ranged from 1.2 to $3.7 \mathrm{U} /$ day when six urine concentrates prepared from six consecutive 24 -hr urine collections from the same donor were assayed in groups of polycythemic mice.

\section{Clinical studies}

Normal volunteers. Nine volunteer male inmates from the Texas Department of Corrections served as controls. Basal values for hematocrit ranged from 45 to $50 \%$ and for red cell volume from 950 to $1250 \mathrm{ml} / \mathrm{m}^{2}$. The median body surface area was $1.89 \mathrm{~m}^{2}$. Bone marrow erythroid cellularity ranged from 10 to $15 \%$, iron stores were never depleted, and control values for erythron iron turnover ranged from 14 to $27 \mathrm{mg} /$ day. During the postphlebotomy period, the serum iron never declined below $65 \mu \mathrm{g} / 100 \mathrm{ml}$, the per cent saturation of transferrin always exceeded $20 \%$, and the $\mathrm{t}_{\mathrm{t}}$ for plasma ${ }^{50} \mathrm{Fe}$ disappearance was always longer

TABLE I

Basal and Postphlebotomy Erythrokinetic Parameters*

\begin{tabular}{|c|c|c|c|c|c|c|c|}
\hline & $\begin{array}{c}\text { No. } \\
\text { patients }\end{array}$ & $\mathrm{Fe}$ & $\begin{array}{l}\text { Saturation } \\
\text { transferrin }\end{array}$ & ${ }^{6 F} \mathrm{Fe}$ & PIT $\ddagger$ & EIT & $\begin{array}{l}\text { Red cell } \\
\text { volume }\end{array}$ \\
\hline Normal & & $\mu \mathrm{g} / 100 \mathrm{ml}$ & $\%$ & $\min$ & $m g / d a y$ & $m g / d a y$ & $m l$ \\
\hline Basal & 9 & $\begin{array}{c}123 \\
(86-137)\end{array}$ & $\begin{array}{c}39 \\
(21-48)\end{array}$ & $\begin{array}{c}92 \\
(69-129)\end{array}$ & $\begin{array}{c}33 \\
(22-37)\end{array}$ & $\begin{array}{c}22 \\
(14-27)\end{array}$ & $\begin{array}{c}2200 \\
(1800-2610)\end{array}$ \\
\hline Postphlebotomy & 5 & $\begin{array}{c}90 \\
(67-99)\end{array}$ & $\begin{array}{c}29 \\
(21-30)\end{array}$ & $\begin{array}{c}40 \\
(35-42)\end{array}$ & $\begin{array}{c}66 \\
(58-69)\end{array}$ & $\begin{array}{c}58 \\
(51-64)\end{array}$ & $\begin{array}{c}1490 \\
(1390-1860)\end{array}$ \\
\hline \multicolumn{8}{|l|}{ Anemia } \\
\hline Without ${ }^{50} \mathrm{Fe}$ in legs & $16 \S$ & $\begin{array}{c}103 \\
(55-161)\end{array}$ & $\begin{array}{c}38 \\
(20-71)\end{array}$ & $\begin{array}{c}96 \\
(56-192)\end{array}$ & $\begin{array}{c}21 \\
(14-37)\end{array}$ & $\begin{array}{c}15 \\
(8-26)\end{array}$ & $\begin{array}{c}970 \\
(440-1740)\end{array}$ \\
\hline \multicolumn{8}{|l|}{ With ${ }^{59} \mathrm{Fe}$ in legs } \\
\hline Basal & 6 & $\begin{array}{c}115 \\
(65-156)\end{array}$ & $\begin{array}{c}38 \\
(23-67)\end{array}$ & $\begin{array}{c}85 \\
(64-118)\end{array}$ & $\begin{array}{c}34 \\
(22-59)\end{array}$ & $\begin{array}{c}26 \\
(17-39)\end{array}$ & $\begin{array}{c}1120 \\
(490-1700)\end{array}$ \\
\hline Postphlebotomy & 3 & $\begin{array}{c}66 \\
(50-120)\end{array}$ & $\begin{array}{c}21 \\
(18-36)\end{array}$ & $\begin{array}{c}46 \\
(42-68)\end{array}$ & $\begin{array}{c}41 \\
(35-86)\end{array}$ & $\begin{array}{c}34 \\
(31-66)\end{array}$ & $\begin{array}{c}1140 \\
(1100-1600)\end{array}$ \\
\hline Polycythemia vera & & & & & & . & \\
\hline Basal & 12 & $\begin{array}{c}53 \\
(20-74)\end{array}$ & $\begin{array}{c}14 \\
(4-25)\end{array}$ & $\begin{array}{c}21 \\
(8-27)\end{array}$ & $\begin{array}{c}58 \\
(38-112)\end{array}$ & $\begin{array}{c}54 \\
(35-109)\end{array}$ & $\begin{array}{c}2930 \\
(2160-4850\end{array}$ \\
\hline Postphlebotomy & 5 & $\begin{array}{c}21 \\
(15-56)\end{array}$ & $\begin{array}{c}5 \\
(3-16)\end{array}$ & $\begin{array}{c}14 \\
(7-20)\end{array}$ & $\begin{array}{c}82 \\
(30-134)\end{array}$ & $\begin{array}{c}76 \\
(32-127)\end{array}$ & $\begin{array}{c}1810 \\
(1150-2730\end{array}$ \\
\hline
\end{tabular}

* Median values with ranges in parentheses.

$\ddagger$ PIT = plasma iron turnover; EIT = erythron iron turnover.

$\S$ Includes three patients with nonerythron iron turnover $>50 \%$ of total turnover (5). 
than 30 min (Table I). Basal urinary erythropoietin values fell within the normal range in all (0.6-1.6 U/day).

Polycythemia vera. Seven men and five women with polycythemia vera were studied. In all, the initial hematocrit was greater than 50 (median 57 ), the red cell volume exceeded $1400 \mathrm{ml} / \mathrm{m}^{2}$, and the arterial oxygen saturation was normal $(>93 \%)$. The median body surface area was 1.76 $\mathrm{m}^{2}$. Splenomegaly was confirmed by $\mathrm{X}$-rays of the abdomen in all but one patient. Bone marrow erythroid cellularity was at least $20 \%$, and erythron iron turnover was at least 35 $\mathrm{mg} /$ day. All but two had iron deficiency by the criteria previously defined (Table I). Since the $t_{1}$ for ${ }^{50} \mathrm{Fe}$ disappearance from the plasma was always less than $30 \mathrm{~min}$, iron supply to the bone marrow was considered suboptimal in all. This conclusion was based on the assumption that very rapid clearance rates ( $t$ less than $30 \mathrm{~min}$ ) approach the maximum rate of extraction by the erythroid marrow and signify a decreased iron supply to the marrow (9). Basal erythropoietin was undetectable $(<0.3 \mathrm{U} /$ day $)$ in 5 of 12 patients. In the remaining seven patients, urinary erythropoietin was present at low levels ranging from 0.3 to $0.9 \mathrm{U} /$ day.

Bone marrow failure. 22 patients with chronic anemia from bone marrow failure were studied. Ages ranged from 33 to 78,11 subjects were male, and the hematocrit ranged from 18 to 40 . The median body surface area was $1.79 \mathrm{~m}^{2}$. Diagnoses included multiple myeloma (16), chronic leukemia (3), lymphoma (1), myelofibrosis postsplenectomy (1), and metastatic carcinoma (1). The major mechanism for anemia in all patients was marrow infiltration by abnormal cells. Mild splenomegaly was present in three patients. No patient had received chemotherapy, radiotherapy, or red cell transfusions for at least 2 months before the study period. In all patients, bone marrow iron stores were present, marrow erythroid cellularity was $20 \%$ or less (median $10 \%$ ), and basal erythropoietin was elevated (median $29 \mathrm{U} /$ day). The creatinine clearance exceeded $70 \mathrm{ml} / \mathrm{min}$ in all but six patients. Since the erythropoietin excretion of the six patients with mild renal impairment (creatinine clearance $35-70 \mathrm{ml} / \mathrm{min}$ ) fell within the range for erythropoietin response to anemia in patients with normal creatinine clearance (>70 ml-min) (vide infra Fig. 2), these studies were included in this analysis. In all patients, the blood urea nitrogen was less than $25 \mathrm{mg} / 100 \mathrm{ml}$.

Patients with significant hemolytic anemia or ineffective erythropoiesis were excluded from this study. No patient in this study had a hemolytic rate, calculated from the ratio between the fixed red cell iron turnover ( $\mathrm{mg} /$ day) and the red cell volume $(\mathrm{ml})$, greater than $2 \%$ per day (normal range $0.8-1.3 \%$ per day). The median rate of hemolysis was $1.6 \%$ per day for both anemic and polycythemic groups. Six anemic patients considered to have significant ineffective erythropoiesis were excluded when total erythropoiesis derived from the erythron iron turnover (5) (plasma iron turnover minus Cook's estimate of nonerythron turnover) exceeded by more than $70 \%$ the rate of effective erythropoiesis derived from the fixed red cell iron turnover. In all of these patients, marrow erythroid cellularity was more than $20 \%$, and the per cent utilization of ${ }^{50} \mathrm{Fe}$ was less than $50 \%$. Table I indicates that the serum iron concentration was similar in the normal and anemic groups, but it was low in patients with polycythemia vera. No patient in this study had a per cent utilization of injected ${ }^{50} \mathrm{Fe}$ less than $50 \%$.

Phlebotomy procedures. Erythrocytophoresis was done in five normal subjects, in five patients with polycythemia vera, and in three patients with chronic anemia. In normal men, $740-1300 \mathrm{ml}$ of red blood cells were removed within 3 days, reducing the red cell volume to $580-670 \mathrm{ml} / \mathrm{m}^{2}$ (median $640 \mathrm{ml} / \mathrm{m}^{2}$ ). In polycythemic patients, the red cell volume was reduced to $810-1000 \mathrm{ml} / \mathrm{m}^{2}$ (median $890 \mathrm{ml} / \mathrm{m}^{2}$ ) by removal of $1990-3310 \mathrm{ml}$ within 6 days, and in anemic patients, it was reduced to $530-740 \mathrm{ml} / \mathrm{m}^{2}$ (median 590 $\mathrm{ml} / \mathrm{m}^{2}$ ) by removal of $350-420 \mathrm{ml}$ in 1 day. Thus, the degree of anemia induced in the polycythemic patients was not as marked as in the normal and anemic subjects. In all patients bled, the hematocrit was reduced to a median value of $33 \%$ (range 26-37\%). All plasma was returned immediately, and $100 \mathrm{ml}$ of $5 \%$ human serum albumin was given on each day of phlebotomy to prevent significant blood volume changes. In order to control iron supply (12), ferrous gluconate was given in an oral dose of $900 \mathrm{mg} / \mathrm{day}$ to the normal and polycythemic subjects who were bled. Oral iron was discontinued at least $12 \mathrm{hr}$ before the start of a postphlebotomy ferrokinetic procedure.

\section{RESULTS}

Erythropoietin excretion in anemia. The effect of phlebotomy on erythropoietin excretion was evaluated in five normal male volunteers (Fig. 1). Urinary erythropoietin levels rose progressively during the first week, and maximum values were reached 8-12 days after phlebtomy. Excretion remained elevated for $1 \mathrm{wk}$ and

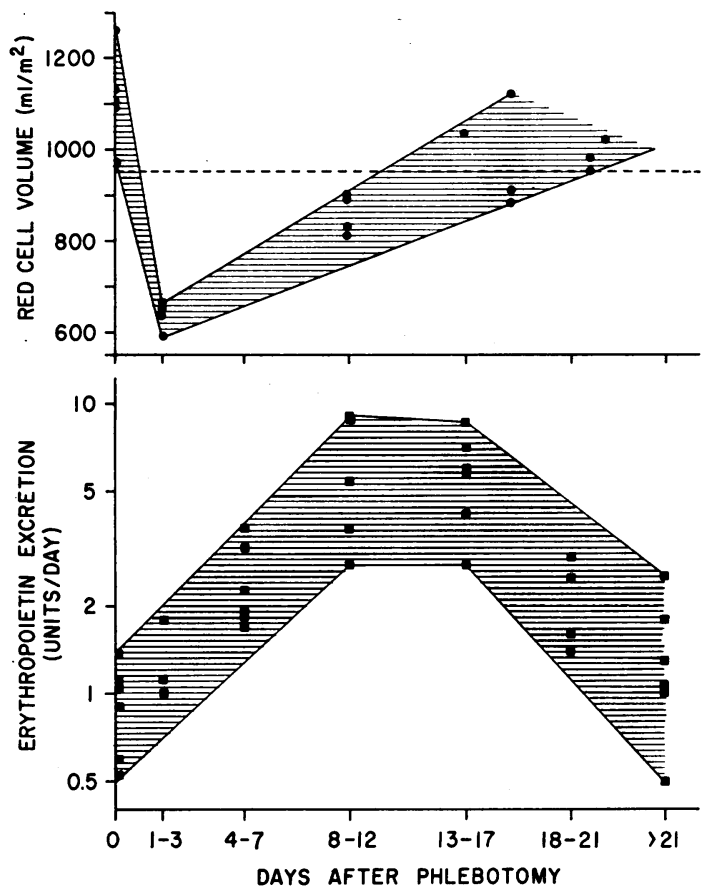

FIGURE 1 Correlation between red cell volume (upper figure) and urinary erythropoietin (lower figure) in five normal subjects after phlebotomy. Erythropoietin values indicate the mean of two or more measurements for days $1-3$, $4-7,8-12,13-17,18-21$, and more than 21 after bleeding. Shaded areas indicate the range for all values. The dotted line in the upper figure indicates the lower limit of the normal range. 
then declined as the red cell volume returned to the normal range. Similar changes occurred in one anemic and in one polycythemic patient. In subsequent studies, the mean erythropoietin response at the 8-12 day time interval after bleeding was compared with the red cell volume.

In 30 normal and anemic males under basal conditions, the erythropoietin excretion increased exponentially with the degree of anemia (shaded area in Fig. 2). In all 13 patients who were bled, the erythropoietin excretion at the new red cell volume was similar to the excretion found in patients with comparable degrees of chronic anemia. In three other patients with polycythemia vera, anemia (red cell volume $<1000 \mathrm{ml} / \mathrm{m}^{2}$ and hematocrit $<35$ ) was maintained for 3-5 months by repeated phlebotomies. After this duration of chronic anemia, the erythropoietin excretion (2.6-4.0 U/day) also fell within

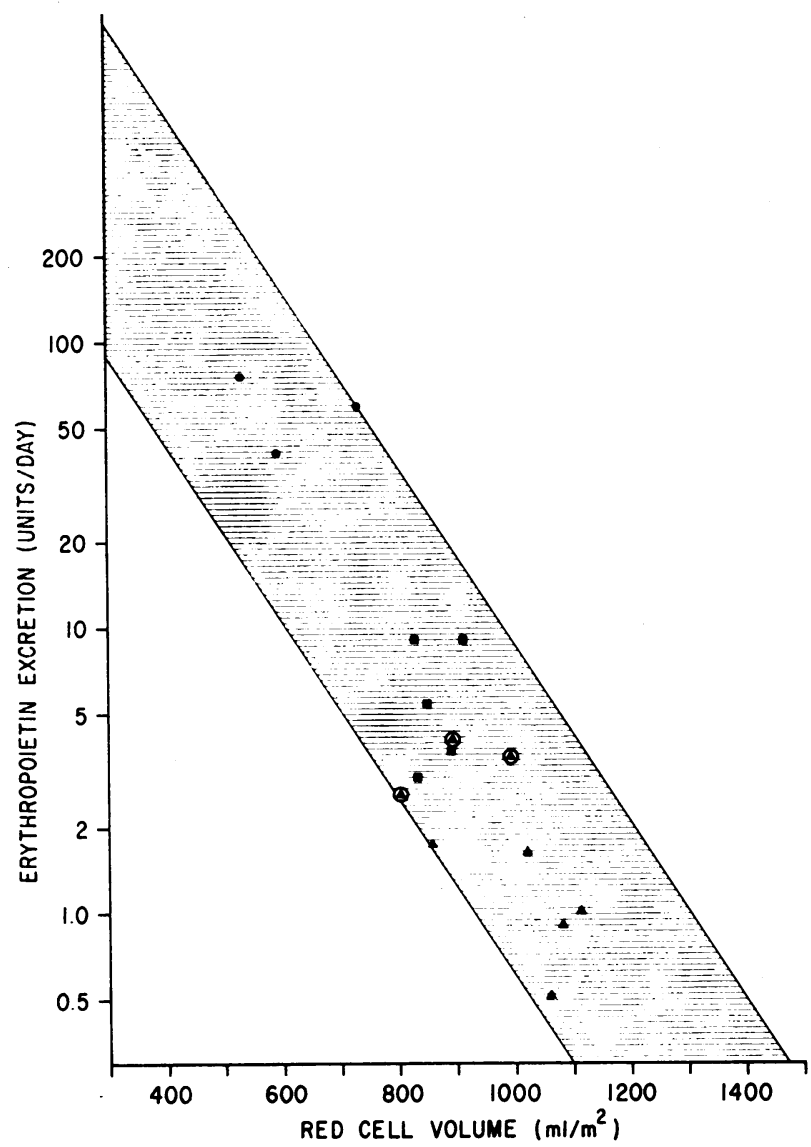

FIGURE 2 Inverse, logarithmic relationship between erythropoietin excretion and red cell volume. The shaded area indicates the range for 30 normal and anemic male subjects in the steady state. Values indicate measurements 10 days after acute anemia in normal $(\boldsymbol{\nabla})$, polycythemia vera $(\boldsymbol{\Delta})$, and anemic (๑) subjects. Circled triangles indicate results in three patients with polycythemia vera after 3-5 months of chronic anemia from repeated phlebotomies.

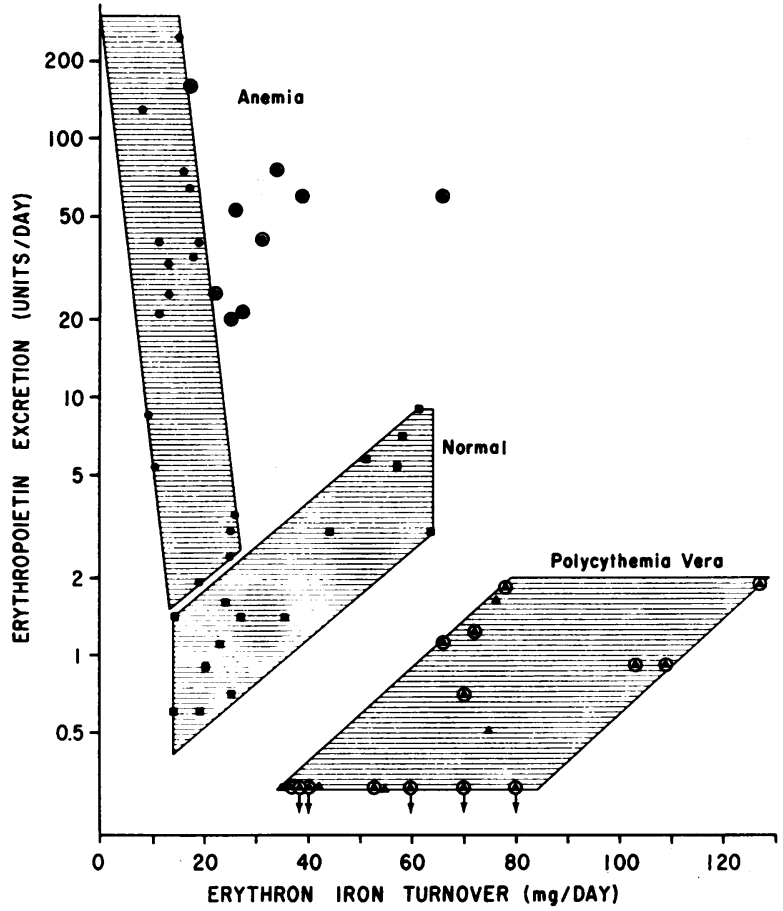

FIGURE 3 Correlation between urinary erythropoietin and erythron iron turnover in normal man ( $\square)$, patients with polycythemia vera $(\boldsymbol{\Delta})$, and anemic patients $(\bullet)$. Circled values indicate studies in patients with increased ${ }^{\infty} \mathrm{Fe}$ uptake over the knees. The shaded areas indicate the range for all values in a group. Points with vertical arrows indicate undetectable levels of erythropoietin.

the range for patients wtih similar degrees of anemia. from marrow failure (Fig. 2).

Erythropoiesis in anemia. The quantitative relationship between erythropoietin excretion and erythron iron turnover was measured. Basal and postphlebotomy values were correlated in normal, anemic, and polycythemic subjects. Fig. 3 indicates the different pattern of marrow response to different levels of erythropoietin in each patient group. In normal man, a 5-fold increase in urinary erythropoietin after phlebotomy was associated with a 2.5 -fold increase in red cell production. In anemic patients, marked elevations in erythropoietin over a 100 -fold range were usually associated with normal or low values for erythron iron turnover. The median erythron iron turnover was $15 \mathrm{mg} / \mathrm{day}$ in the anemic patients without ${ }^{50} \mathrm{Fe}$ activity in the legs, while it was $26 \mathrm{mg} /$ day in those with evidence of bone marrow in the extremities (Table I). In those six patients with peaks of ${ }^{50} \mathrm{Fe}$ over the knees, the median turnover calculated in the legs was $6 \mathrm{mg} /$ day (product of plasma iron turnover and per cent of ${ }^{50} \mathrm{Fe}$ in the legs less $5 \%$ background radioactivity). Thus, in some anemic patients, erythropoiesis in the legs was about one-fourth 
of the level found in the whole bone marrow of normal man. Marrow activity was not detected in the extremities of normal or anemic men unless the erythropoietin excretion exceeded $20 \mathrm{U} /$ day (i.e. $>10$ times normal), but it was present in 9 of 12 patients with polycythemia vera despite low erythropoietin level. (Radioiron activity in the knees was also present in two patients not included in this report with hemolytic anemia and increased iron turnover, but with urinary erythropoietin levels less than $10 \mathrm{U} /$ day.) Table I provides postphlebotomy ferrokinetic data in the 13 patients who were bled. Anemic patients with bone marrow activity in the legs showed an increased level of erythropoiesis after bleeding, although less than the degree of stimulation produced in normal man. In comparison with their own control values, the median elevation of erythron iron turnover in these anemic patients with $40 \%$. In three of the five patients with polycythemia vera who were bled, there was an elevation in erythron iron turnover of at least $20 \%$ (i.e., 18,23 , and $26 \mathrm{mg}$ /day). In the other two patients, no change in iron turnover was found with lower serum iron values.

Marrow maturation time. The rate of red cell matu- ration was determined from the marrow iron transit time at different levels of anemia and erythropoietin stimulation in normal and anemic subjects. No studies with iron-deficient or low utilization erythropoiesis (7 day uptake $<60 \%$ ) were included. All anemic patients in this analysis had erythropoietin excretions greater than 10 times normal (median $33 \mathrm{U} /$ day) with less than three nucleated red cells per 100 white cells on the blood differential smear. Fig. 4 indicates the progressive shortening of marrow transit time in normal man with increasing anemia. Although marrow transit time was short $(<2.9$ days $)$ in 9 of 11 anemic patients, the duration was usually longer (i.e., $>2.2$ days) than that found in normal man 10 days after bleeding (Fig. 4). In only one anemic patient was the red cell maturation time as short as that found in bled, normal subjects. In three anemic patients who were bled further, red cell maturation time was shortened by at least 0.5 day, to a duration similar to that found in a bled, normal man. However, in two of these bled patients, the maturation time remained longer than predicted for the degree of anemia.

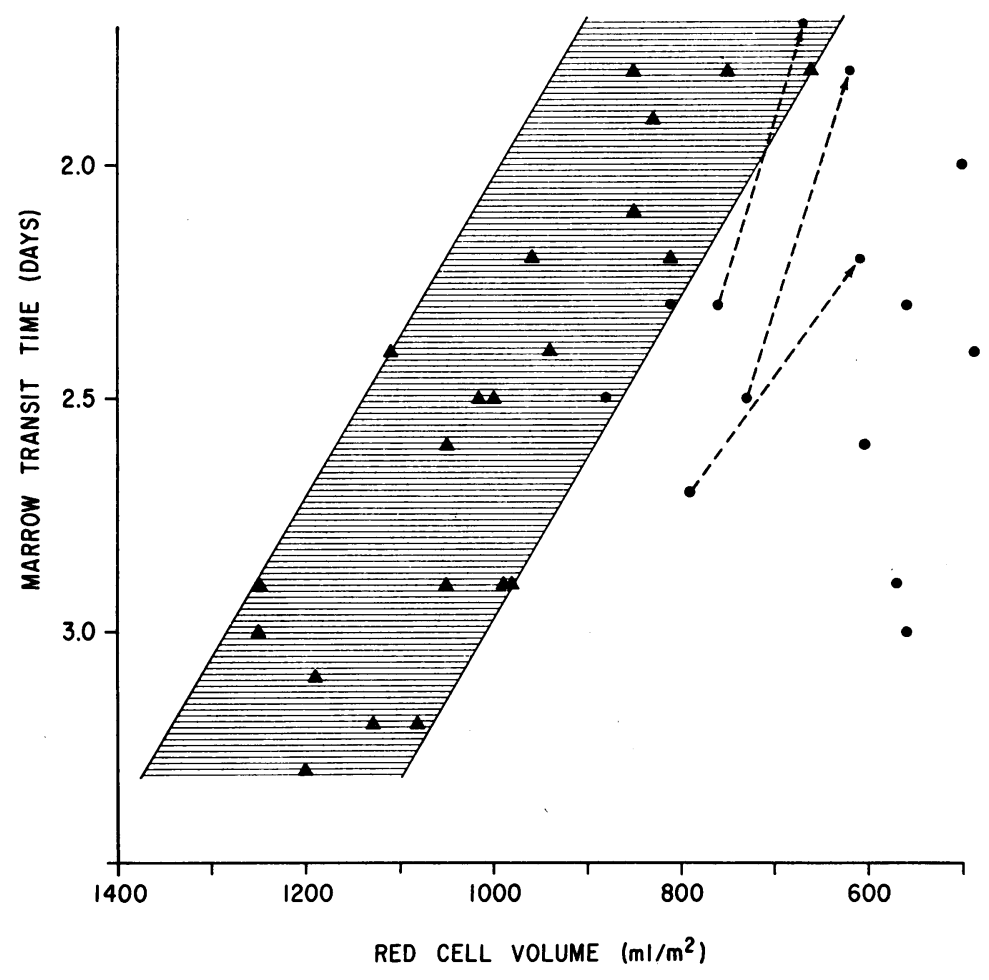

FIgURE 4 Marrow transit time before and after acute anemia in normal man $(\boldsymbol{\Delta})$ and in patients with chronic anemia $(\bullet)$. The shaded area indicates the range for all values in normal man. Less shortening of marrow transit time was apparent in bone marrow failure unless further anemia was induced in three patients (dotted lines). 


\section{DISCUSSION}

This study was designed to evaluate man's capacity to increase erythropoietin production in response to anemia and the effect of different levels of erythropoietin on erythropoiesis. Erythropoietin production was assessed from the daily urinary excretion, although it was recognized that the latter represented a small fraction of the daily production (13). Because of the low reproducibility of the bioassay method, the mean of multiple measurements was used to confirm results for groups of patients. Marrow erythroid activity was quantitated from the erythron iron turnover which was derived from the plasma iron turnover by subtracting that portion of iron turnover committed to nonerythroid sites (5). This calculation provides a valid assessment of the magnitude of erythropoiesis, particularly in anemic patients with severe bone marrow failure. Further precision was added by determining total erythron iron turnover in each subject from concurrent measurements of blood volume. Disorders associated with significant hemolytic anemia and ineffective erythropoiesis were excluded in order to define more clearly the kinetics of erythropoiesis in patients with decreased red cell production due to bone marrow failure. Six patients with mild renal insufficiency were included since anemia was considered to result primarily from bone marrow infiltration by abnormal cells and not from renal failure.

In normal man, phlebotomy induced a predictable elevation in urinary erythropoietin excretion. Although a slight increase was apparent within 2-3 days, the maximum effect occurred about 1 wk later. These findings are similar to Adamson's (14), except that maximum excretion in our study was higher and later. This difference was attributed to our longer period of observation and to a greater depletion of red cell volume. The reason for the slow development of maximum urinary erythropoietin levels was not clear. Conceivably, large amounts of erythropoietin produced during the initial several days after phlebotomy were used by primordial cells in the bone marrow, so that less was available for urinary excretion. After $1 \mathrm{wk}$, an equilibrium between high erythropoietin production and marrow consumption may have been reached so that an increased urinary excretion became more apparent. In any case, return to control levels occurred simultaneously with restitution of a normal red cell volume. These studies support an important role for erythropoietin in the homeostasis of red cell proliferation and define the time kinetics for changes in urinary erythropoietin after bleeding.

The direct relationship between the degree of chronic anemia and the erythropoietin excretion conforms with the results of other investigators $(2,15)$. In addition, the maximum erythropoietin excretion after bleeding patients with different initial red cell volumes was similar to the steady-state levels found in patients with chronic anemia. No quantitative impairment in the capacity to produce erythropoietin was detected in patients with polycythemia vera when results were correlated with the red cell volume. The lower erythropoietin levels in these patients were attributed to the less severe anemia induced by the experimental procedure. When more marked anemia was maintained in polycythemic patients for a longer duration, erythropoietin levels were higher, but again appropriate for the degree of anemia. These observations indicate that the capacity to produce erythropoietin is not suppressed by prolonged polycythemia, a conclusion that might be inferred when results are correlated with the hematocrit (14). In addition, no exaggeration of erythropoietin excretion was found in anemic patients who were bled, suggesting that chronic anemia does not increase the sensitivity of the erythropoietin-producing system to further tissue hypoxia. Thus, erythropoietin production in man is regulated primarily by the degree of anemia, the duration of anemia having little influence after the initial several days of adjustment.

The effect of a specific level of erythropoietin on the rate of erythropoiesis differed in normal, anemic, and polycythemic patients. In normal man, a 5-fold increase in urinary erythropoietin was associated with a doubling of red cell production. In patients with polycythemia vera, low or undetectable levels of erythropoietin were found with inappropriately increased levels of erythropoiesis even though most of the these patients were iron deficient. If iron supply had been adequate, even higher rates of erythropoiesis would probably have been documented for these patients (12). This conforms with the autonomous proliferation of erythroblasts considered to occur in patients with polycythemia vera (16). An elevated rate of red cell production was induced by phlebotomy in some polycythemic patients despite more severe iron deficiency. If one assumes that the increased erythropoiesis was mediated by an increased erythropoietin production provoked by phlebotomy, a primordial cell population in the bone marrow must have responded to erythropoietin. Krantz has reported that the bone marrow of patients with polycythemia vera is insensitive to erythropoietin (17). Our observations suggest that the bone marrow of patients with polycythemia vera may contain the following two populations of cells: one population that is more prevalent, autonomous, and resistant to erythropoietin (17), and a normal population that responds to erythropoietin when increased levels become available.

In anemic patients with marked elevations of erythropoietin, red cell production was greater in those with evidence of marrow activity in the extremities. Thus, a 
major factor contributing to a maximum marrow compensation for anemia in patients with bone marrow disease is increased erythroid activity in previously dormant sites of erythropoiesis. Why only a minority of patients are able to develop red cell production in such areas, despite marked erythropoietin stimulation, is not clear. Increased erythropoietin production is a prerequisite for such marrow activity. A long duration of erythropoietin stimulation also may be necessary since patients with a long history of hemolytic anemia or polycythemia vera are more likely to show increased erythropoiesis in the extremities $(8,18)$. Finally, the less extensive infiltration below the mid-femur by certain malignancies may provide a more normal anatomy for compensatory erythropoiesis in some patients (19).

Progressive shortening of marrow maturation time was found in normal subjects with increasing anemia. This observation has been reported previously by Hillman (20), who attributed the accelerated release of red cells from the bone marrow to an increased production of erythropoietin induced by bleeding. However, in patients with chronic anemia due to bone marrow failure, less shortening of maturation time was apparent for the degree of anemia. Only when anemic patients were bled further to provoke a higher erythropoietin level did marrow maturation time shorten to the degree found in normal subjects. These observations indicate that erythropoietin is not the only factor that affects maturation time and that a normal marrow response also is required. Thus, while shortening of marrow maturation time probably reflects increased erythropoiesis due to erythropoietin in patients with normal marrow function (e.g., hemolytic anemia) (9), anemias due to marrow disease will not show maximal shortening despite even higher erythropoietin levels.

\section{ACKNOWLEDGMENTS}

We are indebted to the Texas Department of Corrections, particularly to $\mathrm{Mr}$. W. Dee Kutach, for providing an opportunity to study inmate volunteers. Brenda Doherty, Eloise Smith, and Jane Yakel assisted with the technical procedures.

This work was supported by U. S. Public Health Service Grants AM 09155 and HE 05435. A portion of this work was done at a Clinical Research Center facility supported by Grant CA 05831 .

\section{REFERENCES}

1. Jacobson, L. O., E. Goldwasser, and C. W. Gurney. 1956. Transfusion-induced polycythemia as a model for studying factors influencing erythropoiesis. In Ciba Foundation Symposium on Haemopoiesis. Little, Brown and Company, Boston. 423.
2. Van Dyke, D. C., M. Layrisse, J. H. Lawrence, J. F. Garcia, and M. Pollycove. 1961. Relation between severity of anemia and erythropoietin titer in human beings. Blood. 18: 187.

3. Giblett, E. R., D. H. Coleman, G. Pirzio-Biroli, D. M. Donohue, A. G. Motulsky, and C. A. Finch. 1956. Erythrokinetics: quantitative measurements of red cell production and destruction in normal subjects and patients with anemia. Blood. 11: 291.

4. Bothwell, T. H., and C. A. Finch. 1962. Iron Metabolism. Little, Brown and Company, Boston. 1st edition.

5. Cook, J. D., G. Marsaglia, J. W. Eschbach, D. D. Funk, and C. A. Finch. 1970. Ferrokinetics: a biologic model for plasma iron exchange in man. J. Clin. Invest. 49: 197.

6. Fudenberg, H., M. Baldini, J. P. Mahoney, and W. Dameshek. 1961. The body hematocrit/venous hematocrit ratio and the "splenic reservoir." Blood. 17: 71.

7. Donohue, D. M., A. G. Motulsky, E. R. Giblett, G. Pirzio-Biroli, V. Viranuvatti, and C. A. Finch. 1955. $\mathrm{Cr}^{61}$ as a red cell tag. Brit. J. Haematgl. 1: 249.

8. Alfrey, C. P., Jr., E. C. Lynch, and R. A. Hettig. 1969. Studies of iron kinetics using a linear scanner. I. Distribution of sites of uptake of plasma iron in hematological disorders. J. Lab. Clin. Med. 73: 405.

9. Finch, C. A., K. Deubelbeiss, J. D. Cook, J. W. Eschbach, L. A. Harker, D. D. Funk, G. Marsaglia, R. S. Hillman, S. Slichter, J. W. Adamson, A. Ganzoni, and E. R. Giblett. 1970. Ferrokinetics in man. Medicine (Baltimore). 49: 17

10. Hartsock, R. J., E. B. Smith, and C. S. Petty. 1965. Normal variations with aging of the amount of hematopoietic tissue in bone marrow from the anterior iliac crest. Amer. J. Clin. Pathol. 43: 326.

11. Alexanian, R., W. K. Vaughn, and M. W. Ruchelman. 1967. Erythropoietin excretion in man following androgens. J. Lab. Clin. Med. 70: 777.

12. Hillman, R. S., and P. A. Henderson. 1969. Control of marrow production by the level of iron supply. J. Clin. Invest. 48: 454.

13. Alexanian, R. 1969. Correlations between erythropoietin production and excretion. J. Lab. Clin. Med. 74: 614.

14. Adamson, J. W. 1968. The erythropoietin/hematocrit relationship in normal and polycythemic man: implications of marrow regulation. Blood. 32: 597.

15. Hammond, D., N. Shore, and N. Movassaghi. 1968. Production, utilization, and excretion of erythropoietin. Erythropoietin. N. Y. Acad. Sci. 149: 516.

16. Van Dyke, D., M. L. Nohr, and J. H. Lawrence. 1966. Erythropoietin in the urine of normal and erythropoietically abnormal human beings. Blood. 28: 535 .

17. Krantz, S. B. 1968. Response of polycythemia vera marrow to erythropoietin in vitro. J. Lab. Clin. Med. 71: 999.

18. Van Dyke, D., and H. O. Anger. 1965. Patterns of marrow hypertrophy and atrophy in man. J. Nucl. Med. 6: 109 .

19. Hashimoto, M. 1962. Pathology of bone marrow. Acta Haematol. 27: 193.

20. Hillman, R. S. 1969. Characteristics of marrow production and reticulocyte maturation in normal man in response to anemia. J. Clin. Invest. 48: 443. 